\title{
13. PRELIMINARY DATA ON DISSOLVED HEAVY METALS IN INTERSTITIAL WATER FROM THE BAY OF BENGAL, LEG $116^{1}$
}

\author{
Toshio Ishizuka, ${ }^{2}$ Yukio Kodama, ${ }^{2}$ Hodaka Kawahata, ${ }^{3}$ and Venugopalan Ittekkot ${ }^{4}$
}

\begin{abstract}
Preliminary data are presented on dissolved heavy metals in interstitial water samples collected at Site 718 of Ocean Drilling Program Leg 118.

The heavy metals at this site are divided into three groups: Group I ( $\mathrm{B}, \mathrm{K}, \mathrm{Mn}, \mathrm{Ni}, \mathrm{Pb}$, total Si, total P, V) behaves like $\mathrm{Mg}$, which decrease with depth; Group Il (Ba, Cu, $\mathrm{Sr}, \mathrm{Ti})$ behaves like $\mathrm{Ca}$, which increases with depth; and Group Ill ( $\mathrm{Cd}, \mathrm{Co}, \mathrm{Cr}, \mathrm{Fe}, \mathrm{Na}, \mathrm{Mo}, \mathrm{Zn})$ contains metals that are independent of depth.

$\mathrm{Mg}$ decreases with depth from $50 \mathrm{mM}$ at the seafloor to $21 \mathrm{mM}$ at $900 \mathrm{mbsf}$. Mn in the sulfate reduction zone (1.0 to $2.8 \mathrm{ppm}$ ) is more highly concentrated than in the methane fermentation zone ( 0.23 to $0.50 \mathrm{ppm})$, except for Section 116-718-1H-1. A similar behavior is also observed for $\mathrm{V}$ and $\mathrm{Pb} . \mathrm{Ni}, \mathrm{B}$, and $\mathrm{K}$ decrease non-uniformly with depth.

$\mathrm{Ca}$ and $\mathrm{Sr}$ increase with depth at the same rates, indicating the dissolution of inorganic calcium carbonate by anaerobic oxidation of organic matter (Sayles, 1981). The distribution of Ba with depth is very similar to those of $\mathrm{Ca}$ and $\mathrm{Sr}$. $\mathrm{Cu}$ and $\mathrm{Ti}$ profiles trend to increase non-uniformly with depth.

$\mathrm{Fe}$ is constant with depth. The sharp decrease in total silicate concentration at the seafloor probably indicates a decrease in the decomposition of siliceous biological matter (e.g., diatoms) and production of opal. The constant levels of Group IIl, except for $\mathrm{Na}$ and $\mathrm{Fe}$, may reveal equal sources of supply from surface seawater and the Himalayas over time.
\end{abstract}

\section{INTRODUCTION}

Understanding the behavior of heavy metals in interstitial water under conditions of sulfate reduction and methane fermentation is important in geochemical studies, especially those relating to early diagenesis of heavy metals. Decay and oxidation of organic matter (Emerson et al., 1980) leads to a manifold increase in $\mathrm{Mn}, \mathrm{Fe}, \mathrm{Cu}, \mathrm{Ni}$, and $\mathrm{Zn}$ contents of marine interstitial water (Hartmann and Mueller, 1979 and Klinkhammer, 1980). Although many studies have focused attention on the major elements in interstitial water (e.g., Berner, 1980; Gieskes, 1983; Gieskes and Lawrence, 1981; McDuff, 1981; Manheim, 1978; Manheim and Bischoff, 1989; Sayles and Manheim, 1975; Sholkovitz, 1973), only a few have addressed problems concerning the distribution of heavy metals (e.g., Brooks, et a1., 1968, Klinkhammer, 1980, Sawlan and Murry, 1983). Within surficial sediments, oxidants are reduced sequentially: first $\mathrm{O}_{2}, \mathrm{NO}_{3}$, followed by $\mathrm{MnO}_{2}$ and $\mathrm{Fe}_{2} \mathrm{O}_{3}$ and then by $\mathrm{SO}_{4}^{2-}$.

However, little is known about the effects of this reduction sequence on the distribution of metals deeper in the sediment column. Available data indicate that $\mathrm{Ca}$ in interstitial water decreases during sulfate reduction followed by a concomitant $\mathrm{Ca}$ and $\mathrm{Sr}$ increase at greater depths. Following $\mathrm{SO}_{4}^{2-}$ reduction, $\mathrm{Mg}$ decreases with depth in pelagic sediment during early diagenesis (Gieskes, 1983). The increase of both $\mathrm{Ca}$ and $\mathrm{Sr}$ and the decrease of $\mathrm{Mg}$ at the depth in the sediment column of interstitial water implies recrystalization of carbonate (Sayles and Manheim, 1975) or reaction with clay minerals.

Preliminary results of both heavy metal and major cation analyses in interstitial water samples collected at Site 718 in

\footnotetext{
${ }^{1}$ Cochran, J. R., Stow, D.A.V., et al., 1990. Proc. ODP, Sci. Results, 116: College Station, TX, U.S.A. (Ocean Drilling Program).

${ }^{2}$ Ocean Research Institute, University of Tokyo, Nakano, Tokyo, 164 Japan.

${ }^{3}$ Geological Survey of Japan, Tsukuba, 305 Japan.

${ }^{4}$ University of Hamburg, Geological-Paleontological Institute, Bundesstrasse 55,200 Hamburg, Federal Repubic of Germany.
}

the Bay of Bengal are presented here. Site 718 is located in the central Indian Ocean approximately $800 \mathrm{~km}$ south of Sri Lanka and $200 \mathrm{~km}$ northwest of the Afanasiy Nikitin seamount group (Fig. 1).

\section{METHODS}

Interstitial water samples were obtained with an automatic stainless steel mechanical squeezer and sealed in polythene tubes, which were pre-washed with $2 \mathrm{M} \mathrm{HNO}_{3}$. Samples were acidified to about $2 \mathrm{M}$ with $14 \mathrm{M} \mathrm{HNO}_{3}$, which was made by sub-boiling distillation of guaranteed reagent (Mattinson, 1972).

We analyzed the heavy metals in the interstitial water samples using an inductively coupled plasma emission spectrometry (ICP). The instrumental components and operating conditions for the Seiko JY $48 \mathrm{P}(\mathrm{V})$ with cross-flow-type nebulizer are summarized in Table 1 . The operating conditions were set according to recommended procedures. The analytical calibration curves were determined using the blank and mixed standard solutions of all the elements investigated (analytical standard solutions for atomic absorption analysis, Wako Chemical Co.). We could not measure three elements $(\mathrm{Cd}, \mathrm{Cu}, \mathrm{Pb})$ due to the $\mathrm{Ca}$ effect of interstitial water on the ICP instrument. They were analyzed by graphite atomic absorption spectrophotometry on a Hitachi Z-8000. Na and $\mathrm{K}$ of interstitial water were measured by flame atomic absorption spectrometry (Hitachi, Z-8000). $\mathrm{Ca}$ and $\mathrm{Mg}$ concentrations of the interstitial water that were measured by the ICP agree to within $5 \%$ of the titration analyses made on board ship (Table 2 and Shipboard Scientific Party, 1989). The analysis of heavy metals reported below are accurate to within 5\% (Table 3).

\section{RESULTS}

The stratigraphic section recovered at the Site 718 ranges from late Quaternary to early Miocene. The sediments are dominated by mud, silty mud, and silty turbidites, some of which are characterized by relatively high organic carbon 


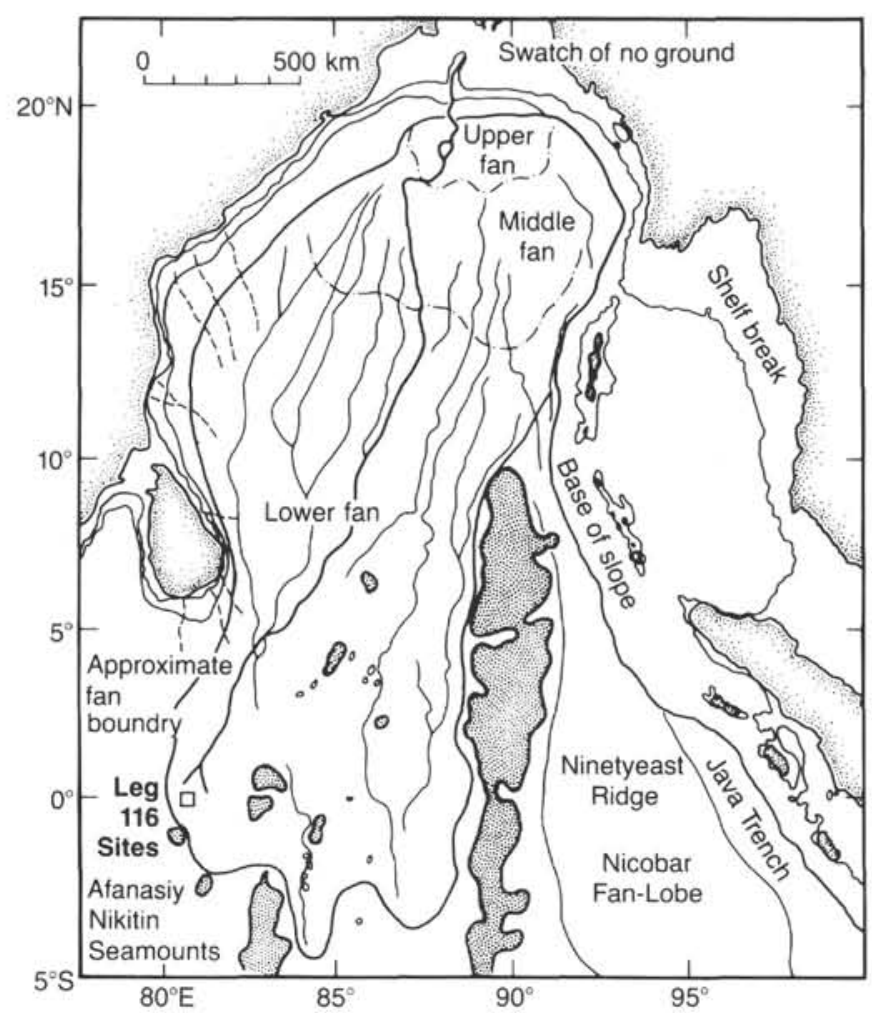

Figure 1. Location of ODP Site 718 in Bay of Bengal.

Table 1. Instrumental and Operating Conditions.

\begin{tabular}{ll}
\hline ICP spectrometer & Seiko JY $48 \mathrm{P}(\mathrm{V})$ \\
Frequency & $27.12 \mathrm{MHz}$ \\
Output power & $1.3 \mathrm{KW}$ \\
Coolant gas & argon $16 \mathrm{~L} / \mathrm{min}$. \\
Auxiliary gas & argon $0.6 \mathrm{~L} / \mathrm{min}$. \\
Carrier gas & argon $0.4 \mathrm{~L} / \mathrm{min}$. \\
Observation high & $16 \mathrm{~mm}$ above work coil \\
Nebulizer & cross-flow type \\
Polycnromator & Paschen-Runge type $(100 \mathrm{~cm}$ focal length) \\
Grating & 2550 grooves/mm \\
Reciprocal linear dispersion & $0.39 \mathrm{~nm} / \mathrm{mm}$ at $270 \mathrm{~nm}$ \\
Entrance slit width & $20 \mu \mathrm{m}$ \\
Exit slit width & $38 \mu \mathrm{m}$ \\
\hline
\end{tabular}

contents $(0.2$ to $2.5 \mathrm{wt} \%)$ in the sulfate reducing zone extending down to about $200 \mathrm{mbsf}$, but display lower organic carbon content $(<0.5 \mathrm{wt} \%)$ in the methane fermentation zone below 200 mbsf.

Foraminifers are sporadic to absent throughout the section with the exception of the top few meters, which have a more abundant planktonic assemblage. However, the profile of calcium carbonate shows an increase on average from $5 \%$ to $20 \%$ with depth (about $5 \%$ down to 250 mbsf, $10 \%$ between 250 and 700 mbsf, and $10 \%$ to $20 \%$ below $700 \mathrm{mbsf}$ ) (Leg 116 shipboard Scientific Party, 1989). This increase in calcium carbonate may be the result of inorganic carbonate such as that reported by Ishizuka and Mori (in press).

The $\mathrm{Ca}$ concentration of the interstitial water is approximately constant $(8.3-10 \mathrm{mM})$ with depth in the zone of sulfate reduction, but increases from 11.0 to $18.0 \mathrm{mM}$ with depth within the zone of methane fermentation (Fig. 2A). The constant increase of $\mathrm{Sr}$ (6.1 to $7.9 \mathrm{ppm}$ down to $200 \mathrm{mbsf}$ and 11.0 to $17.0 \mathrm{ppm}$ below $200 \mathrm{mbsf}$ ) with depth shows a similar profile to that of $\mathrm{Ca}$ (Fig. 2B). Dissolution of calcium carbon- ate by anaerobic oxidation of organic matter (Sayles, 1981) is indicated by the fact that $\mathrm{Ca}$ and $\mathrm{Sr}$ increase at the same rate. The $\mathrm{Ba}$ profiles with depth closely match $\mathrm{Ca}$ and $\mathrm{Sr}$ in behavior (Fig. 2C). The reasons for this similarity are not known, but it may relate to the absorption of clay minerals or biogenic residue. $\mathrm{Cu}$ and $\mathrm{Ti}$ profiles tend to increase nonuniformly with depth (Figs. 2D and 2E). Cu is typically closely associated with a labile solid phase, to which it becomes attached near the sea-sediment interface (Klinkhammer, 1980; Sawlan and Murry, 1983).

$\mathrm{Mg}$ concentration shows a constant level (46 to $46 \mathrm{mM}$ except for the Section 118-718-1H-4) down to $10 \mathrm{mbsf}$, then decreases with depth ( 46 to $21 \mathrm{mM}$ ) between 10 and $500 \mathrm{mbsf}$, and becomes constant again ( 21 to $27 \mathrm{mM}$ ) below $500 \mathrm{mbsf}$ (Fig. 4). Goldberg and Arrhenius (1958) demonstrated that the $\mathrm{Mg}$ content of biogenic carbonate is very low. Therefore, most of the $\mathrm{Mg}$ is not in the lattice of carbonate, but probably $\mathrm{Mg}$ absorbed onto clay minerals by cation exchange. This is indicated also by the difference between increase of calcium $(\Delta \mathrm{Ca}=6 \mathrm{mM})$ and decrease of $\mathrm{Mg}-\Delta \mathrm{Mg}=25 \mathrm{mM})$. The $\mathrm{K}$ content is constant 20 to $24 \mathrm{mM}$ (down to $10 \mathrm{mbsf}$ ), and decreases from 20 to $3.2 \mathrm{mM}$ with depth between 100 and 400 mbsf and then varies markedly from 5.4 to $18.0 \mathrm{mM}$ below 400 mbsf (Fig. 3A). By contrast the Na content shows an irregular variation ( 370 to $410 \mathrm{mM}$ ) with depth (Fig. 3B). These results are different from those of Sayles (1981), in which Na release and $\mathrm{K}$ uptake are related to silicate reaction.

Both total phosphate and total silicate (Figs. 3C and 3D) decrease with depth down to $300 \mathrm{mbsf}$, from 1.4 to $0.17 \mathrm{ppm}$ and from 13.0 to $3.8 \mathrm{ppm}$, respectively. This indicates either biological reaction or reaction with calcium phosphate, in addition to the silicate reaction. The B decrease in pore water (Fig. 3E) may reflect the replacement of $\mathrm{K}$ in illite as proposed by (Harder, 1959). However, as both B and K decrease with depth at Site 718, this may suggest either replacement of other elements in clay minerals or the authigenesis of illite.

$\mathrm{Ni}$ shows a general decrease with depth (Fig. 3F). Mn shows higher concentrations in the sulfate reduction zone $(1.0$ to $2.8 \mathrm{ppm})$ than in the methane fermentation zone $(0.23$ to $0.50 \mathrm{ppm}$ ), except for the Section $116-7181 \mathrm{H}-1$, even though the $\mathrm{MnO}_{2}$ reduction occurs before $\mathrm{Fe}$ and sulfate reduction (Fig. 4A). $\mathrm{V}$ and $\mathrm{Pb}$ have similar behaviors to $\mathrm{Mn}$ with depth (Figs. $4 \mathrm{~B}$ and $4 \mathrm{C}$ ). V shows 53 to $64 \mathrm{ppb}$ in the sulfate reduction zone, 27 to $39 \mathrm{ppb}$ in the methane fermentation zone, and $\mathrm{Pb}$ ranges from 100 to $130 \mathrm{ppb}$ in the sulfate reduction zone and 41 to $83 \mathrm{ppb}$ in the methane fermentation zone. The $\mathrm{Pb}$ and $\mathrm{V}$ concentrations may depend on redox conditions within the sediments.

Total silicate decreases with depth, 13 to $5.9 \mathrm{ppm}$, only in near-surface sediment. It is then approximately constant, 5.9 to $6.8 \mathrm{ppm}$, in the sulfate reduction zone and fluctuates more widely, 3.4 to $8.3 \mathrm{ppm}$, in the methane fermentation zone. The sharp decrease of the total silicate just below the seafloor may indicate a decrease in the rate of decomposition of siliceous biological matter (e.g., diatoms) and authigenesis of opal.

$\mathrm{Cd}, \mathrm{Cr}, \mathrm{Co}, \mathrm{Fe}, \mathrm{Mo}, \mathrm{Zn}$, and $\mathrm{Zr}$ are approximately constant with depth (e.g., Figs. 4D, 4E, and 4F). Cd, Co, Zn, and Fe decrease or increase with depth in the southern California Borderland and Santa Barbara and Santa Crus Basins (Brooks et a1., 1968). These authors suggested that enrichment of $\mathrm{Cd}$, $\mathrm{Co}, \mathrm{Cu}$, and $\mathrm{Zn}$ in surface sediments could be attributed to biological concentration and release, as there was more than sufficient organic matter present to account for such a source. However, at Site 718 there is very little fresh organic matter in surface sediments so that the relatively low concentrations of heavy metals are constant with depth. Fe content is constant with depth because iron reduction occurs before sulfate re- 
duction. The lack of variation of those concentrations except $\mathrm{Fe}$ and $\mathrm{Na}$ may reveal a similar source of supply over time from surface seawater and the Himalayas.

\section{ACKNOWLEDGMENTS}

The authors acknowledge their gratitude and deep appreciation to the late E. T. Degens (Geological-Paleontological Institute, University of Hamburg), who suggested and supervised this work.

\section{REFERENCES}

Berner, R. A., 1980. Early Diagenesis: A Theoretical Approach: Princeton, NJ (Princeton Univ. Press).

Brooks, R. R., Presley, B. J., and Kaplan, I. R., 1968. Trace elements in the interstitial waters of marine sediments. Geochim. Cosmochim. Acta., 32:397-414.

Emerson, S., Jahnke, R., Bender, M., Froelich, P., Klinkhammer, G., Bowser, B., and Setlock, G., 1980. Early diagenesis in sediments from the eastern equatorial Pacific. I. Pore water nutrients and carbonate results. Earth Planet. Sci. Lett., 49:57-80.

Gieskes, J. M., 1983. The chemistry of interstitial waters of deep-sea sediments: interpretation of deep-sea drilling data. In Riley, J. P., and Chester, R. (Eds.), Chemical Oceanography (Vol. 8): London (Academic Press), 222-269.

Gieskes, J. M., and Lawrence, J. R., 1981. Alteration of volcanic matter in deep-sea sediments: evidence from the chemical composition of interstitial waters from deep-sea drilling cores. Geochim. Cosmochim. Acta, 45:1687-1703.

Goldberg, E. D., and Arrhenius, G.O.S., 1958. Chemistry of Pacific pelagic sediments. Geochim. Cosmochim. Acta, 13:153-212.

Harder, H., 1960. Einbau von Bor in detritische Ton-minerale. Geochim. Cosmochim. Acta, 21:284-294.

Hartmann, M., and Mueller, P. J., 1979. Trace metals in interstitial waters from Central Pacific Ocean sediments. In Fanning, K. A. and Manheim, F. (Eds.), The Dynamic Environment of the Ocean Floor: Lexington, Mass. (Lexington Books), 285-301.
Klinkhammer, G. P., 1980. Early diagenesis in sediments from the eastern equatorial Pacific. II. Pore water metal results. Earth Planet. Sci. Lett., 49:81-101.

Manheim, F. T., 1976. Interstitial waters of marine sediments. In Riley, J. P., and Chester, R. (Eds.), Chemical Oceanography (Vol. 6): London (Academic Press), 115-186.

Manheim, F. T., and Bischoff, J. L., 1989. Geochemistry of pore waters from Shell Oil Company drill holes on the continental slope of the northern Gulf of Mexico. Chem. Geol., 4:63-82.

Mattinson, J. M., 1972. Preparation of hydrofluoxic, hydrochloric, and nitric acid at the ultralow lead levels. Anal. Chem., 44:1715.

McDuff, R. E., 1981. Major cation gradients in DSDP interstitial waters: the role of diffusive exchange between seawater and upper ocean crust. Geochim. Cosmochim. Acta, 45:1705-1713.

Sawlan, J. J., and Murry, J. W., 1983. Trace metal remobilization in the interstitial waters of red clay and hemipelagic marine sediments. Earth Planet. Sci. Lett., 64:213-230.

Sayles, F. L., 1981. The composition and diagenesis of interstitial solutions-II. Fluxes and diagenesis at the water -sediment interface in the high latitude North and South Atlantic. Geochim. Cosmochim. Acta., 45:1061-1086.

Sayles, F. L., and Manheim, F. T., 1975. Interstitial solutions and diagenesis in deeply buried marine sediments: results from the Deep Sea Drilling Project. Geochim. Cosmochim. Acta, 39:103128.

Shipboard Scientific Party, 1988. Site 718: Bengal Fan. In Cochran, J. R., Stow, D.A.V., Proc. ODP, Init. Repts., 116: College Station, TX (Ocean Drilling Program), 91-154.

Sholkovitz, E. R., 1973. Interstitial water chemistry of the Santa Barbara Basin sediments. Geochim. Cosmochim. Acta., 37:20432073.

Date of initial receipt: 18 April 1989

Date of acceptance: 24 January 1990

Ms 116B-136

Table 2. Major cation elements in the interstitial water at Site 718. Fl-AA is flame atomic absorption.

\begin{tabular}{|c|c|c|c|c|c|c|c|c|c|c|c|}
\hline Section & $\begin{array}{c}\text { Interval } \\
(\mathrm{cm})\end{array}$ & $\begin{array}{l}\text { Depth } \\
\text { (mbsf) }\end{array}$ & $\begin{array}{c}\mathrm{Na} \\
(\mathrm{nM})\end{array}$ & $\underset{(\mathrm{mM})}{\mathrm{K}}$ & $\underset{(\mathrm{mM})}{\mathrm{Mg}}$ & $\underset{(\mathrm{mM})}{\mathrm{Ca}}$ & $\underset{(\mathrm{ppm})}{\mathrm{Sr}}$ & $\underset{(\mathrm{ppm})}{\mathrm{Ba}}$ & $\begin{array}{c}\mathrm{B} \\
(\mathrm{ppm})\end{array}$ & $\begin{array}{c}\mathrm{Si} \\
(\mathrm{ppm})\end{array}$ & $\underset{(\mathrm{ppm})}{\mathrm{P}}$ \\
\hline \multicolumn{12}{|l|}{$116-718-$} \\
\hline $1 \mathrm{H}-01$ & $40-50$ & 0.45 & 790 & 20.0 & 48 & 9.9 & 7.2 & 0.1 & 5.4 & 11.0 & 0.55 \\
\hline $1 \mathrm{H}-01$ & $140-150$ & 1.4 & 810 & 23.0 & 48 & 10.0 & 7.5 & 0.2 & 7.2 & 13.0 & 1.40 \\
\hline IH- 03 & $140-150$ & 4.4 & 820 & 23.0 & 49 & 10.0 & 7.7 & 0.1 & 6.9 & 9.2 & 0.72 \\
\hline 1H-04 & $140-150$ & 5.9 & 810 & 23.0 & 39 & 8.3 & 6.1 & 0.1 & 6.5 & 5.9 & 0.83 \\
\hline $1 \mathrm{H}-05$ & $130-140$ & 7.3 & 780 & 20.0 & 46 & 9.7 & 7.1 & 0.1 & 5.9 & 6.5 & 0.62 \\
\hline $1 \mathrm{H}-05$ & $140-150$ & 7.4 & 820 & 21.0 & 47 & 10.0 & 7.3 & 0.2 & 5.9 & 6.1 & 0.65 \\
\hline $1 \mathrm{H}-06$ & $0-10$ & 7.5 & 800 & 20.0 & 47 & 9.8 & 7.1 & 0.1 & 5.8 & 6.3 & 0.63 \\
\hline IH-06 & $140-150$ & 8.9 & 770 & 20.0 & 46 & 9.7 & 7.0 & 0.2 & 5.8 & 6.6 & 0.61 \\
\hline $13 \mathrm{X}-01$ & $140-150$ & 125 & 820 & 18.0 & 42 & 10.0 & 7.9 & 0.2 & 6.5 & 6.1 & 0.37 \\
\hline $15 \mathrm{X}-01$ & $140-150$ & 144 & 740 & 13.0 & 37 & 9.4 & 7.9 & 0.2 & 6.2 & 5.9 & 0.46 \\
\hline $25 X-01$ & $140-150$ & 239 & 760 & 7.9 & 28 & 11.0 & 11.0 & 0.9 & 4.5 & 4.1 & 0.34 \\
\hline $29 X-01$ & $128-138$ & 268 & 790 & 9.9 & 30 & 11.0 & 12.0 & 1.3 & 3.4 & 4.8 & 0.17 \\
\hline $32 \mathrm{X}-02$ & $140-150$ & 307 & 820 & 10.0 & 30 & 11.0 & 11.0 & 2.5 & 2.8 & 3.8 & 0.26 \\
\hline $36 X-01$ & $130-140$ & 343 & 770 & 3.2 & 26 & 12.0 & 13.0 & 4.6 & 4.5 & 6.3 & 0.39 \\
\hline $49 X-01$ & $140-150$ & 467 & 720 & 5.7 & 21 & 13.0 & 13.0 & 6.3 & 3.9 & 8.3 & 0.26 \\
\hline $55 X-02$ & $140-150$ & 525 & 820 & 16.0 & 26 & 14.0 & 13.0 & 6.2 & 2.7 & 5.0 & 0.29 \\
\hline $59 \times-03$ & $140-150$ & 565 & 790 & 5.4 & 21 & 13.0 & 16.0 & 6.5 & 2.3 & 3.4 & 0.28 \\
\hline $62 X-03$ & $140-150$ & 593 & & & 24 & 15.0 & 16.0 & 1.5 & 3.5 & 5.7 & 0.34 \\
\hline $90 X-01$ & $140-150$ & 856 & 820 & 15.0 & 27 & 16.0 & 17.0 & 3.1 & 4.9 & 6.7 & 0.26 \\
\hline \multicolumn{3}{|c|}{ Analytical Method } & Fl-AA & Fl-AA & ICP & ICP & ICP & ICP & ICP & ICP & ICP \\
\hline
\end{tabular}


Table 3. Heavy metals in the interstitial water at Site 718. GF-AA is graphite atomic absorption.

\begin{tabular}{|c|c|c|c|c|c|c|c|c|c|c|c|c|c|c|c|}
\hline Section & $\begin{array}{l}\text { Interval } \\
\text { (cm) }\end{array}$ & $\begin{array}{l}\text { Depth } \\
\text { (mbsf) }\end{array}$ & $\begin{array}{c}\mathrm{Pb} \\
\text { (ppb) }\end{array}$ & $\begin{array}{c}\mathrm{Ti} \\
(\mathrm{ppb})\end{array}$ & $\begin{array}{c}\mathrm{Zr} \\
(\mathrm{ppb})\end{array}$ & $\underset{(\mathrm{ppb})}{\mathrm{V}}$ & $\begin{array}{c}\mathrm{Cr} \\
(\mathrm{ppb})\end{array}$ & $\begin{array}{c}\text { Mo } \\
\text { (ppb) }\end{array}$ & $\begin{array}{c}\mathrm{Mn} \\
(\mathrm{ppm})\end{array}$ & $\begin{array}{c}\mathrm{Fe} \\
(\mathrm{ppb})\end{array}$ & $\begin{array}{c}\mathrm{Co} \\
\text { (ppb) }\end{array}$ & $\begin{array}{c}\mathrm{Ni} \\
(\mathrm{ppb})\end{array}$ & $\begin{array}{c}\mathrm{Cu} \\
(\mathrm{ppb})\end{array}$ & $\begin{array}{c}\mathrm{Zn} \\
(\mathrm{ppb})\end{array}$ & $\begin{array}{c}\mathrm{Cd} \\
\text { (ppb) }\end{array}$ \\
\hline \multicolumn{16}{|l|}{ 116-718- } \\
\hline $1 \mathrm{H}-01$ & $40-50$ & 0.45 & 100 & 15 & 0.8 & 61 & 3.1 & 35 & 0.22 & 32 & 0.4 & 18 & 99 & 190 & 12 \\
\hline $1 \mathrm{H}-03$ & $140-150$ & 4.4 & 110 & 16 & 0.8 & 59 & 1.8 & 34 & 2.80 & 760 & 1.2 & 79 & 170 & 510 & 14 \\
\hline $1 \mathrm{H}-04$ & $140-150$ & 5.9 & 100 & 14 & 3.4 & 54 & 52.0 & 29 & 1.70 & 100 & 0.8 & 58 & 39 & 160 & 10 \\
\hline $1 \mathrm{H}-05$ & $130-140$ & 7.3 & 110 & 16 & 3.0 & 58 & 5.2 & 25 & 1.70 & 420 & 1.5 & 39 & 480 & 150 & 11 \\
\hline $1 \mathrm{H}-05$ & $140-150$ & 7.4 & 120 & 18 & 5.0 & 64 & 11.0 & 32 & 1.50 & 120 & 2.6 & 120 & 280 & 210 & 16 \\
\hline $15 \mathrm{X}-01$ & $140-150$ & 144 & 120 & 17 & 7.0 & 53 & 2.4 & 26 & 1.00 & 35 & 1.6 & 60 & 830 & 400 & 14 \\
\hline $25 \mathrm{X}-01$ & $140-150$ & 239 & 72 & 14 & n.d. & 35 & 13.0 & 28 & 0.23 & 34 & 1.5 & 23 & 320 & 850 & 27 \\
\hline $29 \mathrm{X}-01$ & $128-138$ & 268 & 41 & 13 & n.d. & 33 & 50.0 & 21 & 0.48 & 240 & 1.9 & 38 & 150 & 270 & 31 \\
\hline $32 \mathrm{X}-02$ & $140-150$ & 307 & 78 & 15 & n.d. & 39 & 5.2 & 33 & 0.50 & 550 & 1.0 & 11 & 160 & 99 & 11 \\
\hline $36 \mathrm{X}-01$ & $130-140$ & 343 & 86 & 19 & 4.0 & 36 & 8.8 & 29 & 0.39 & 74 & 1.4 & 38 & 540 & 400 & 13 \\
\hline $49 \mathrm{X}-01$ & $140-150$ & 467 & 68 & 18 & 6.0 & 32 & 3.0 & 26 & 0.45 & 31 & 1.3 & 27 & 140 & 150 & 20 \\
\hline $55 \mathrm{X}-02$ & $140-150$ & 525 & 86 & 19 & 4.0 & 36 & 3.1 & 36 & 0.34 & 28 & 1.2 & 26 & 320 & 300 & 14 \\
\hline $59 \mathrm{X}-03$ & $140-150$ & 565 & 63 & 16 & n.d. & 27 & 2.0 & 24 & 0.25 & 29 & 0.7 & 34 & 370 & 130 & 18 \\
\hline
\end{tabular}


$\mathrm{Ca}(\mathrm{mM})$

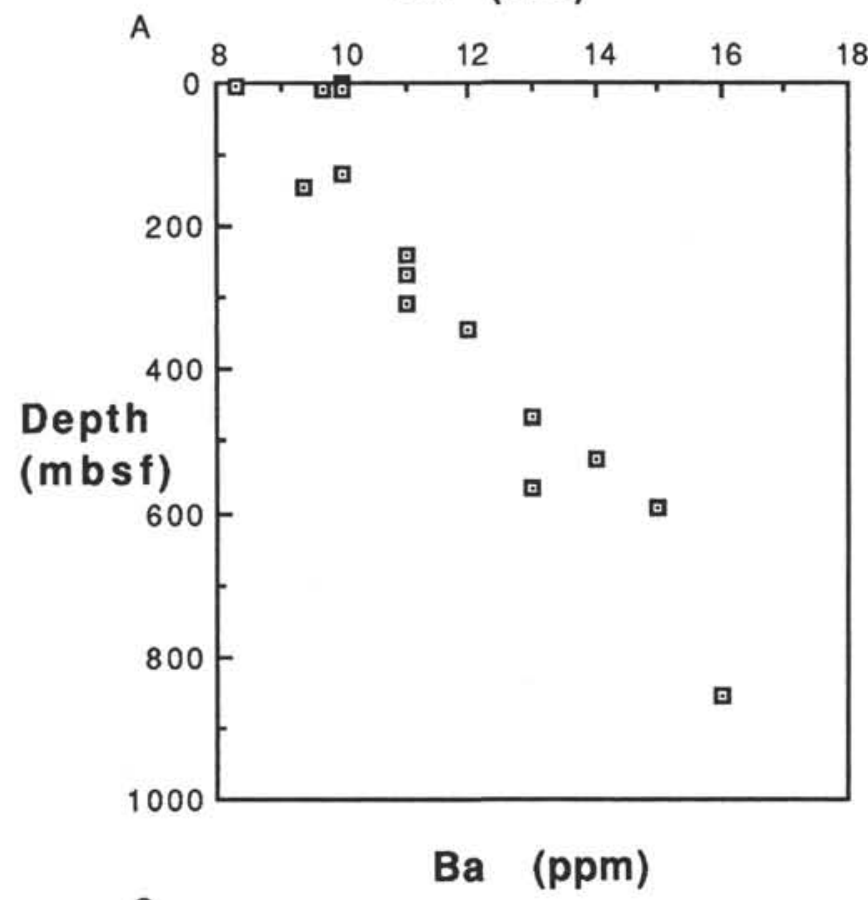

C

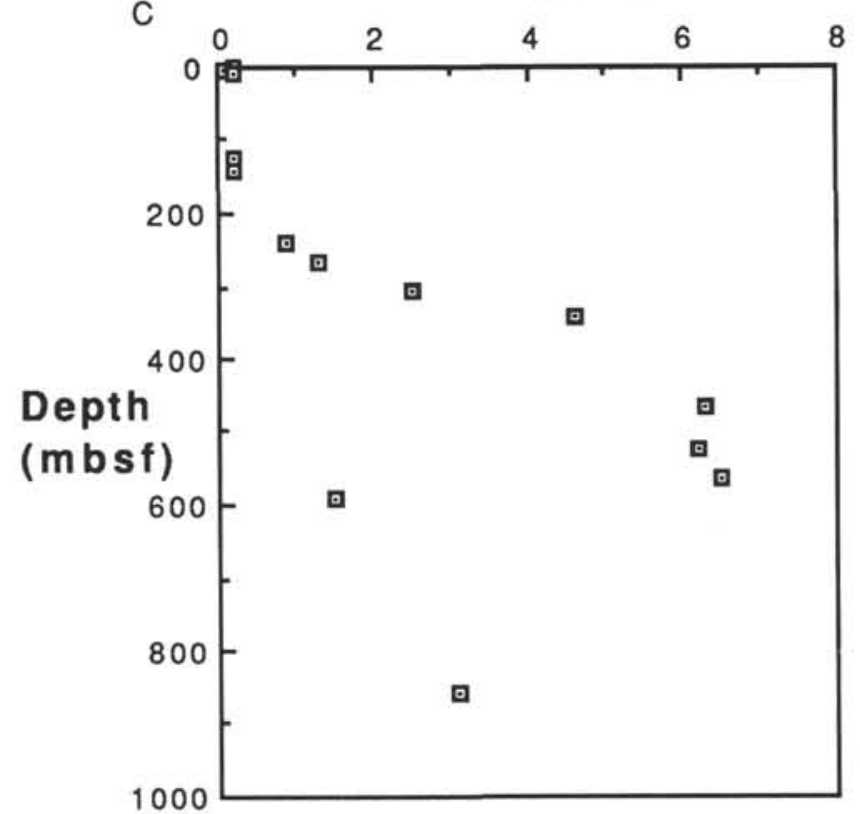

$\mathrm{Sr} \quad(\mathrm{ppm})$

B
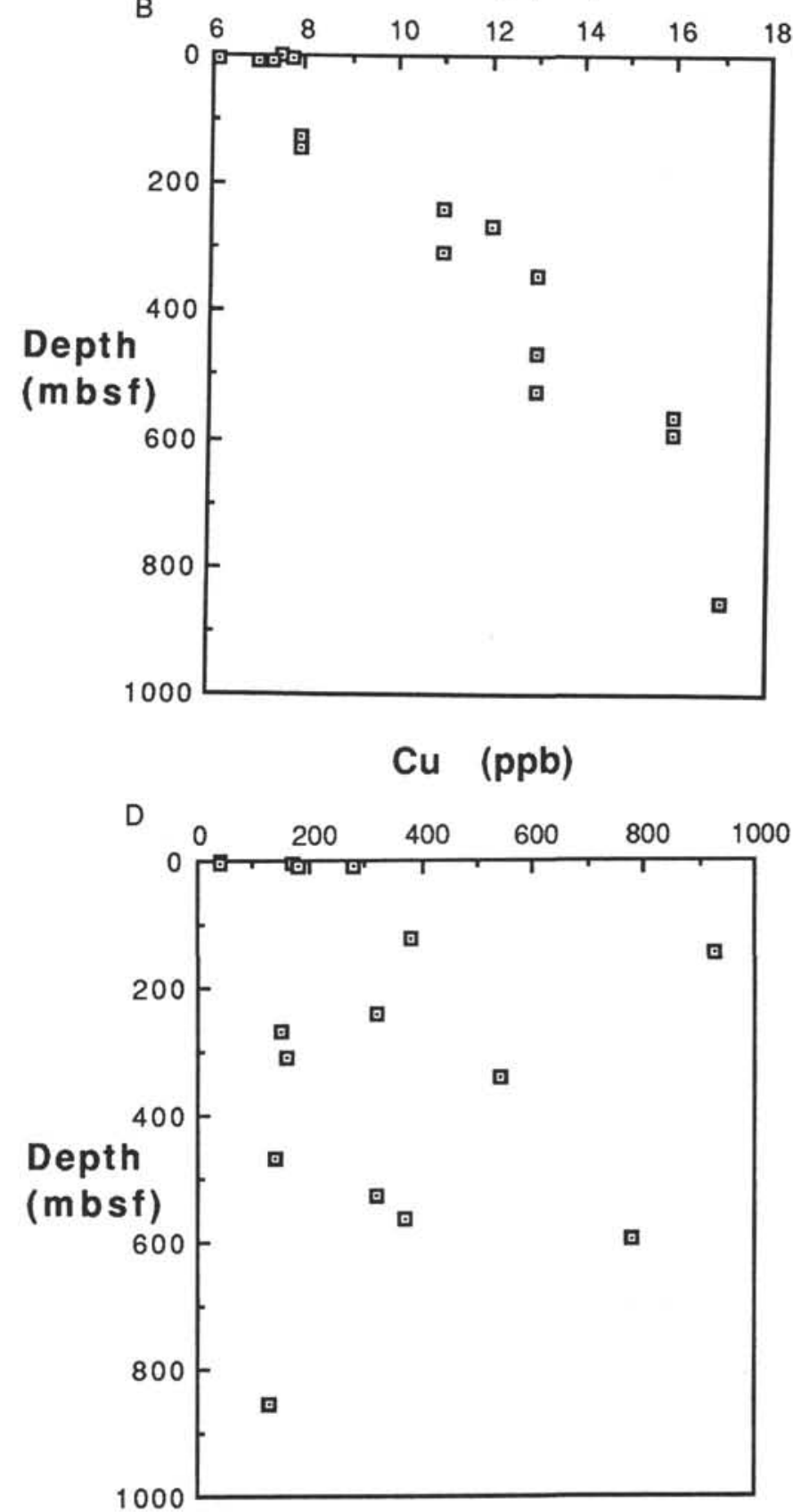

Figure 2. Profiles of interstitial water with depth at Site 718. A. Ca; B. Sr; C. Ba; D. Cu; E. Ti; F. Mg. 


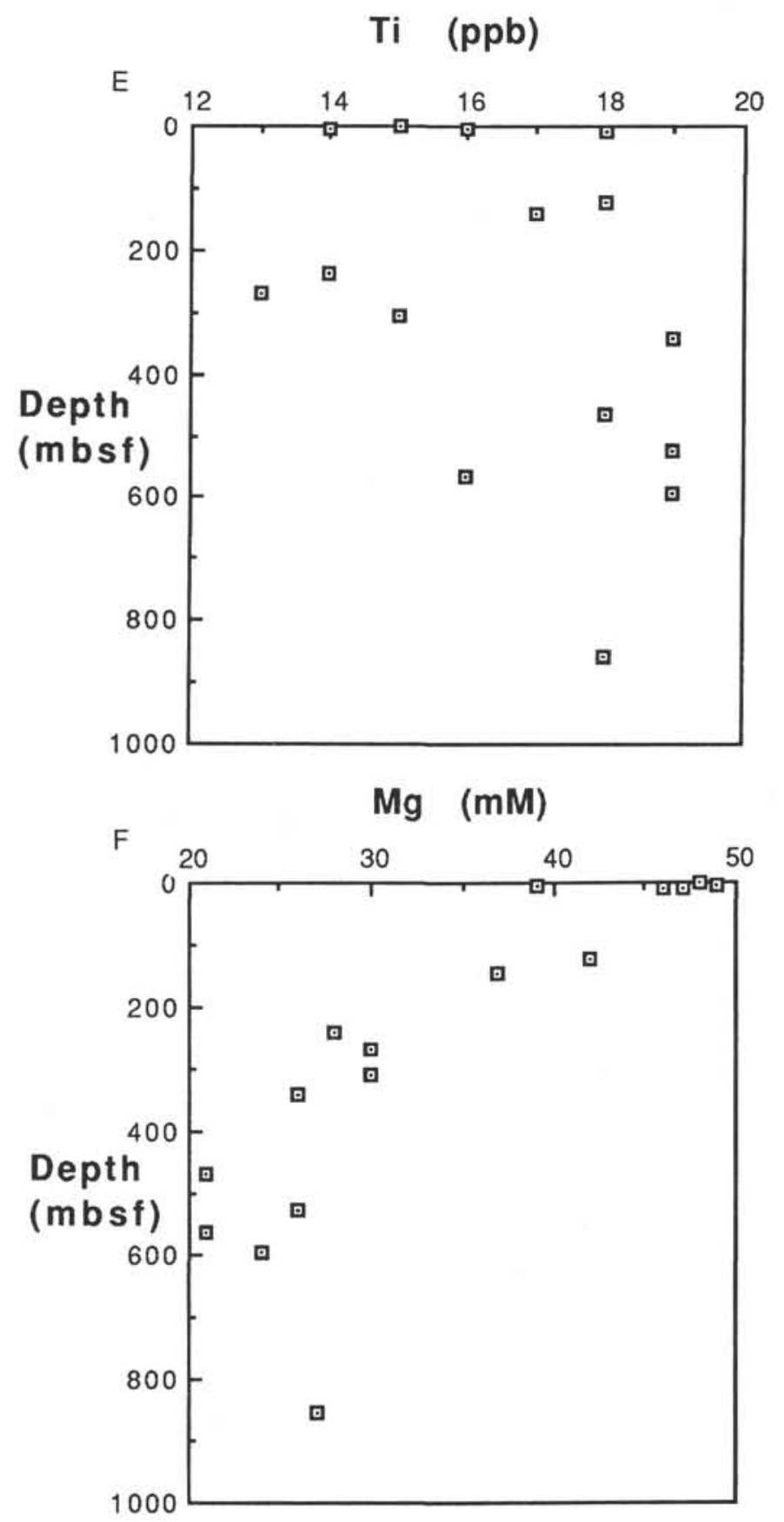

Figure 2 (continued). 

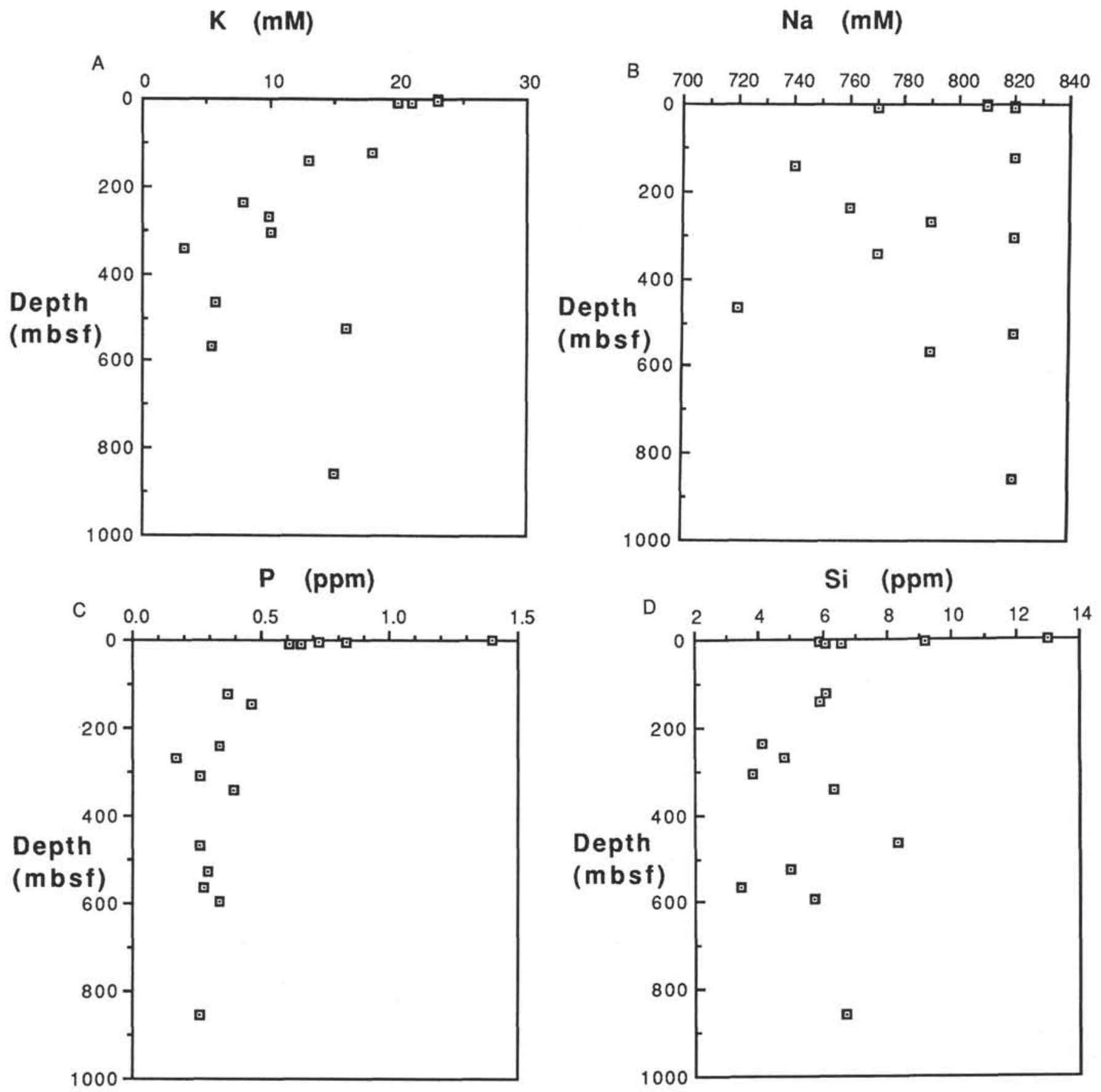

Figure 3. Profiles of interstitial water with depth at Site 718. A. K; B. Na; C. Phosphate; D. Silicate; E. B; F. Ni. 

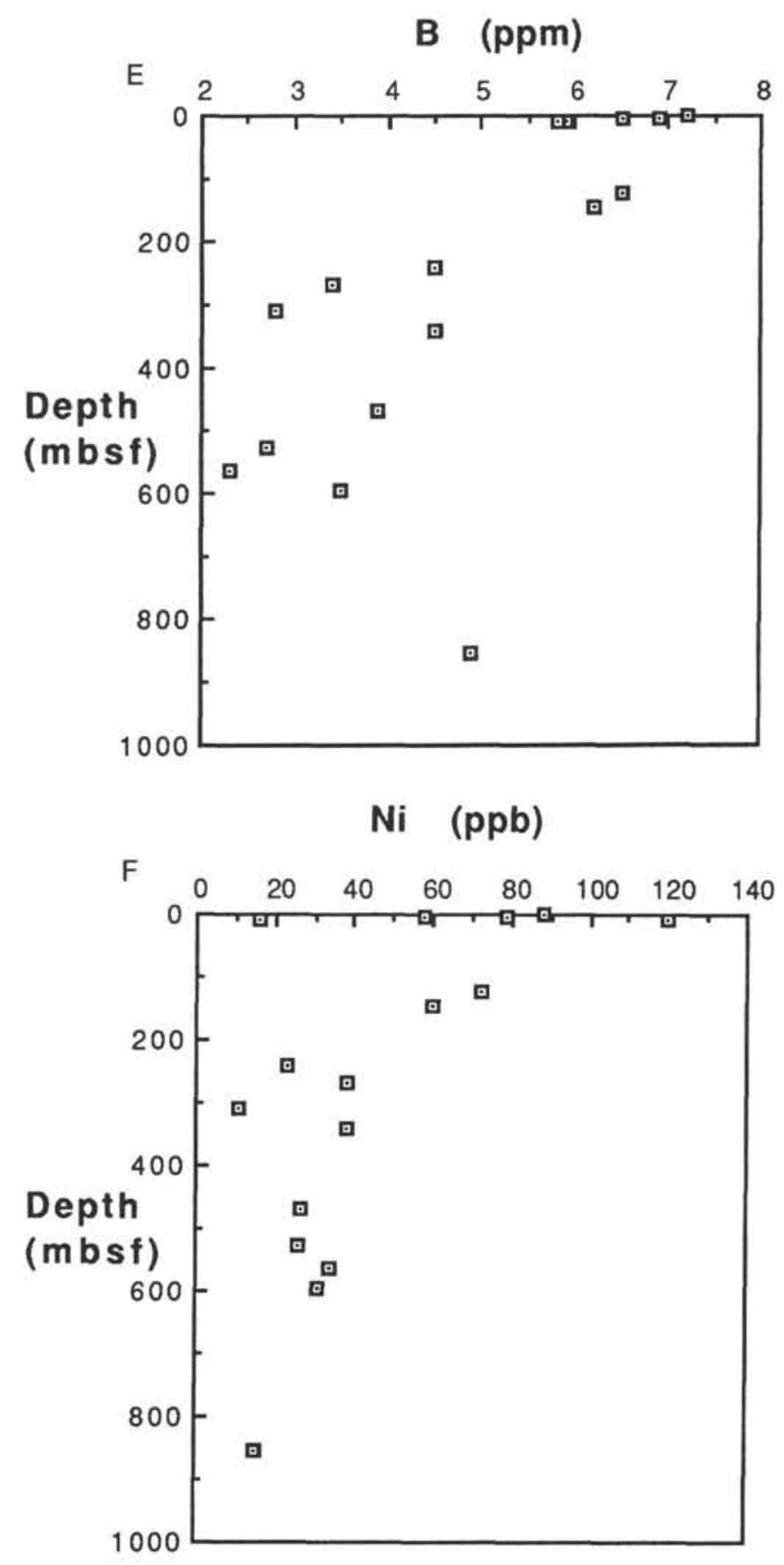

Figure 3 (continued). 

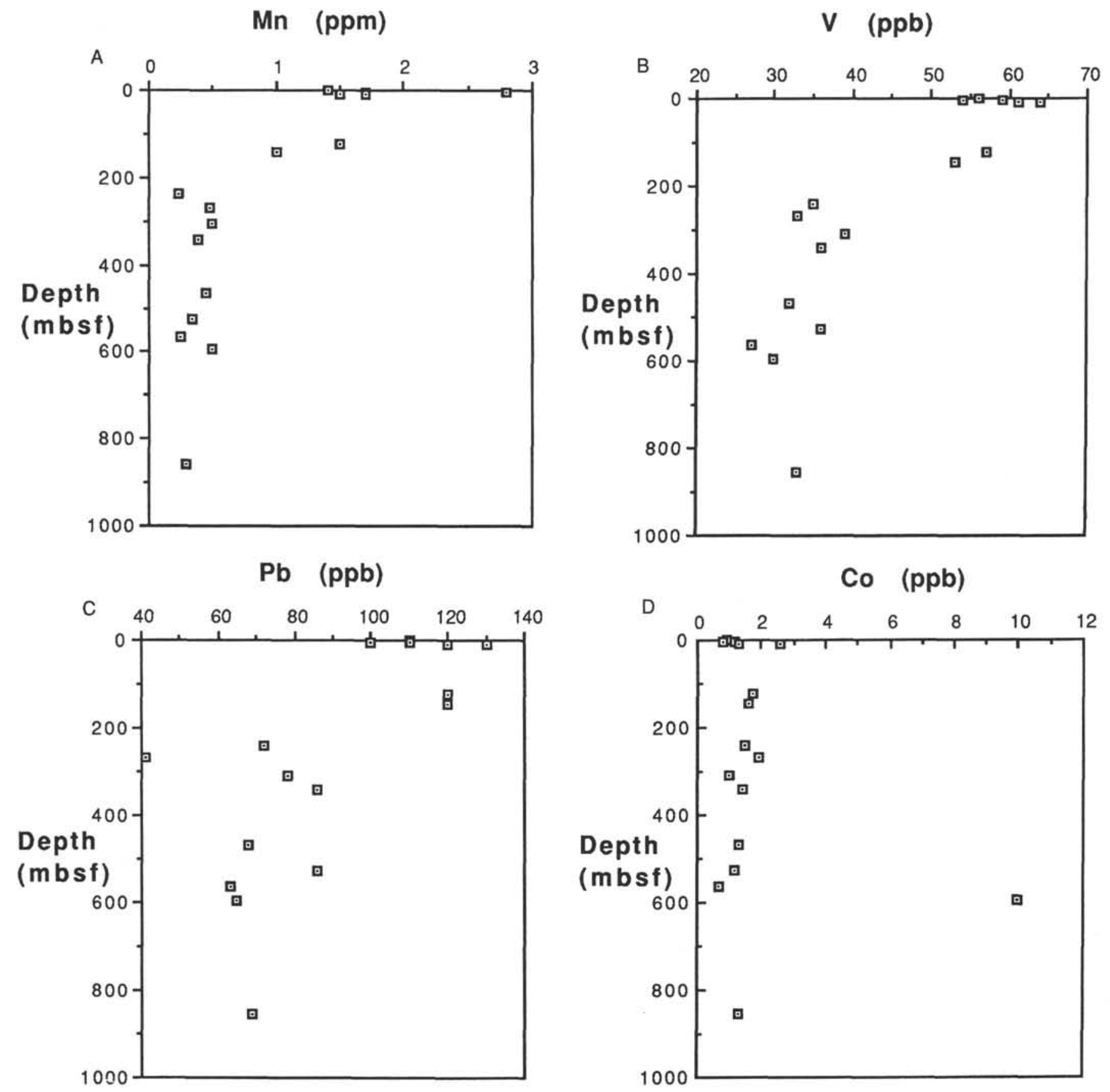

Figure 4. Profiles of interstitial water with depth at Site 718. A. Mn; B. V; C. Pb; D. Co; E. Mo; F. Zn. 

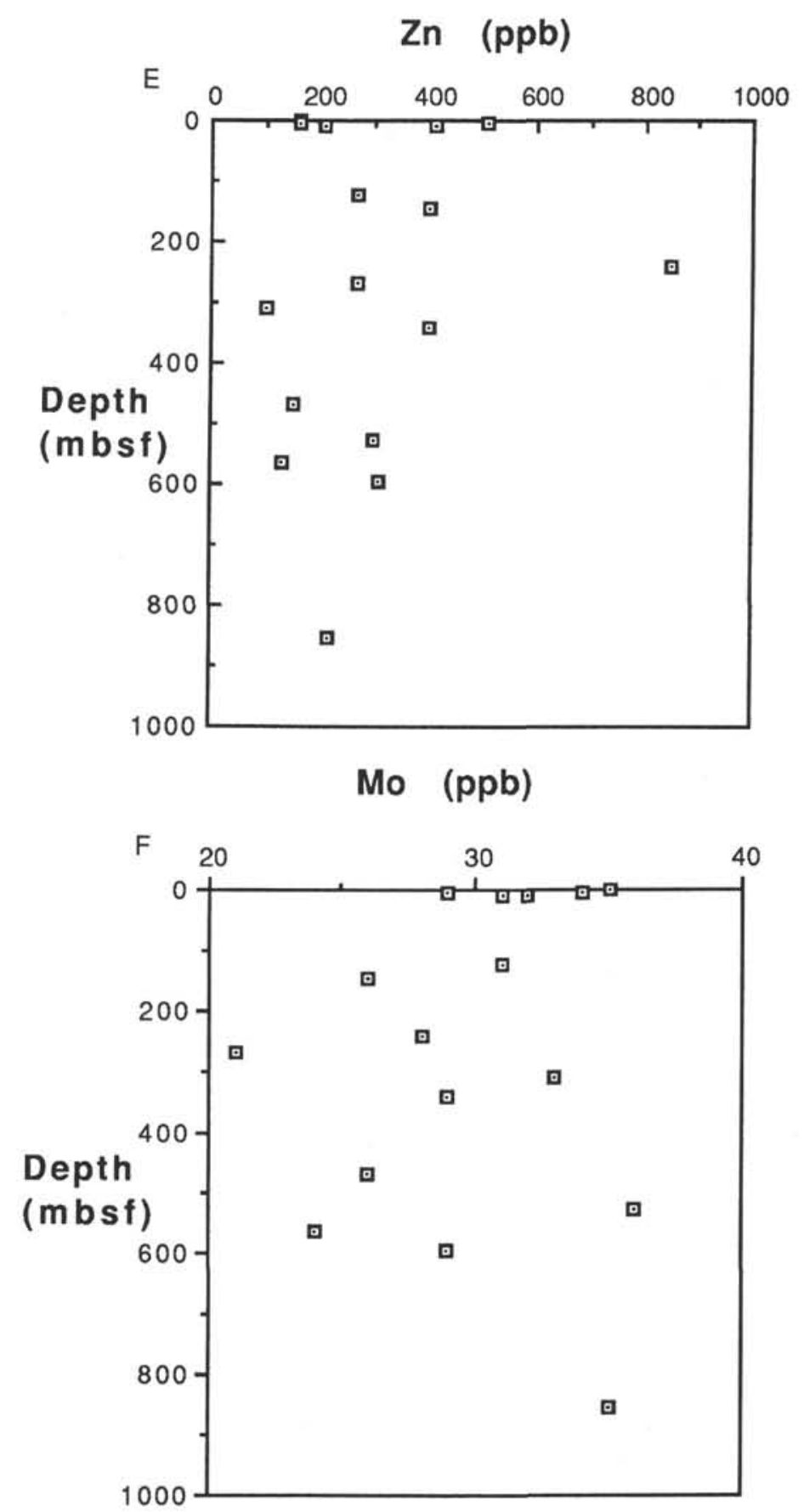

Figure 4 (continued). 